JEBIS: Jurnal Ekonomi dan Bisnis Islam

Vol. 5, No.2, Juli - Desember 2019

p-ISSN : 2442-6563 e-ISSN : 2525-3027

Page $223-240$

\title{
THE EFFECT OF MACROECONOMIC VARIABLES IN PREDICTING INDONESIAN SHARIA STOCK INDEX
}

\author{
Angga Khoerul Umam \\ Program Studi Ekonomi Islam, Fakultas Ekonomi dan Bisnis, Universitas Airlangga \\ Email: khoerulumamangga@yahoo.com \\ Ririn Tri Ratnasari \\ Program Studi Ekonomi Islam, Fakultas Ekonomi dan Bisnis, Universitas Airlangga \\ Email: ririnsari@feb.unair.ac.id \\ Sri Herianingrum \\ Program Studi Ekonomi Islam, Fakultas Ekonomi dan Bisnis, Universitas Airlangga \\ Email: sri.herianingrum@feb.unair.ac.id
}

ARTICLE HISTORY

Received:

2019-08-28

Accepted:

2019-12-04

Online available:

2019-12-31

Keywords:

Exchange Rates, Interest Rates, Industrial

Production Index, ISSI, VECM

\section{ABSTRACT}

This study examines the impact of macroeconomic variables, namely the exchange rate, interest rates, industrial production index, SBIS and inflation on the Indonesian Islamic stock index. This study uses monthly data from May 2011 to December 2018. This research is a quantitative study that applies the Johansen Cointegration Test and Vector Error Correction Model to see the long-term impact and shock response on certain variables. The findings indicate the existence of short-term and long-term causality between macroeconomic variables and the Indonesian Islamic stock index. Especially in the long run, industrial production index and inflation have a significant effect on ISSI, while the exchange rate, interest rates and SBIS have no significant effect on ISSI. IRF results show that the response of each variable and stable at different times. The ISSI response experienced a positive shock that occurred in the industrial production index and inflation. On the other hand, the exchange rate, the Bungan rate and SBIS were responded negatively by ISSI.

\section{ABSTRAK}

Kata Kunci:

Penelitian ini meneliti dampak dari variebel makroekonomi yaitu nilai tukar, suku bunga, indeks produksi industri, SBIS dan inflasi terhadap indeks saham syariah Indonesia. Penelitian ini 
Nilai Tukar, Suku menggunakan data bulanan dari Mei 2011 hingga Desember Bunga, Indeks Produksi Industri, ISSI, VECM 2018. Penelitian ini adalah penelitian kuantitatif yang menerapkan Johansen Cointegration Test dan Vector Error Correction Model untuk melihat dampak jangka panjang dan respon guncangan pada variabel-variabel tertentu. Temuan menunjukkan adanya kausalitas jangka pendek dan jangka panjang antara variabel ekonomi makro dan indeks saham syariah Indonesia. Khususnya dalam jangka panjang, indeks produksi industri dan inflasi berpengaruh signifkan terhadap ISSI, sementara nilai tukar, suku bunga dan SBIS tidak berpengaruh signifikan terhadap ISSI. Hail IRF menunjukkan bahwa respon dari setiap variabel dan stabil pada waktu yang berbeda-beda. Respon ISSI mengalami guncangan positif yang terjadi pada indeks produksi industri dan inflasi. Di sisi lain, nilai tukar, suku Bungan dan SBIS direspon negatif oleh ISSI.

\section{PENDAHULUAN}

Industri keuangan syariah secara global menunjukkan perkembangan yang cukup pesat. Beberapa tahun terakhir terjadi pertumbuhan yang signifikan di industri keuangan syariah khususnya di negara-negara Timur Tengah dan Asia Tenggara yang tumbuh setelah krisis keuangan global (GFC) 2008-2009. Jumlah total aset keuangan syariah yang dikelola diperkirakan US\$ 1,6 triliun pada akhir 2012 dan US\$ 1,8 triliun pada akhir 2013, dan mencapai US\$ 2,1 triliun pada akhir 2014 dan diperkirakan mencapai US\$ 6,5 triliun pada tahun 2020. (Hammoudeh, dkk, 2014). Pertumbuhan ini didukung dengan semakin banyaknya negara-negara di dunia baik negara dengan penduduk mayoritas muslim maupun non-muslim yang mengembangkan keuangan syariah di negaranya. Sebagai contoh Turki dan United Kingdom.

Demikian halnya Indonesia juga terus berupaya mengembangkan keuangan syariah. Walaupun masih relatif kecil dalam skala nasional, perkembangan industri keuangan syariah menunjukkan perkembangan yang cukup signifikan dalam kancah global. Hal tersebut terlihat dari publikasi Global Islamic Finance Report yang menempatkan Indonesia pada peringkat ke-7 Islamic Finance Contry Index untuk tahun 2017 (Global Islamic Finance Report, 2017: 2).

Dalam perkembangannya, industri keuangan syariah di Indonesia memiliki karekteristik yang berbeda dibandingkan negara lain seperti Malaysia dan Gulf Cooperation Council (GCC) yang berfokus pada perbankan, investasi dan instrument keuangan syariah. Indonesia memiliki kompleksitas yang melingkupi banyak jenis industri jasa keuangan serta lebih berorientasi pada segmen ritel. Indonesia mempunyai lembaga jasa keuangan syariah dan nasabah keuangan syariah terbesar dalam satu jurisdiksi tunggal, selain adanya pengembangan hal-hal tertentu yang 
menampilkan karakteristik khas keuangan syariah Indonesia seperti Bank Pembiayaan Rakyat Syariah (BPRS) dan institusi keuangaan mikro syariah informal.

Dari sisi besarnya aset keuangan syariah, dalam beberapa tahun terakhir keuangan syariah di Indonesia telah menunjukkan perkembangan yang signifikan. Posisi Indonesia pada industri keuangan syariah di pasar global juga meningkat sebagai pemain yang diakui di antara pemain terkenal lainnya seperti negara-negara Gulf Cooperation Council (GCC) dan Malaysia. Berdasarkan laporan Islamic Finance Devlopment Report 2017, ICD-Thomson Reuter negara dengan aset keuangan syariah terbesar adalah Iran. Sementara itu, Indonesia termasuk dalam kelompok 10 negara dengan aset keuangan terbesar bersama dengan Saudi Arabia, Malaysia, Uni Emirat Arab, Kuwait, Bahrain, Qatar, Turki, dan Bangladesh. Secara total aset keuangan syariah, Indonesia menempati posisi ke-7 dari total aset keuangan syariah dunia dengan total aset US\$ 81 Miliar, meningkat dari posisi sebelumnya yang menempati posisi ke-9 pada laporan yang sama tahun sebelumnya (Laporan Perkembangan Keuangan Syariah Indonesia, 2017: 6).

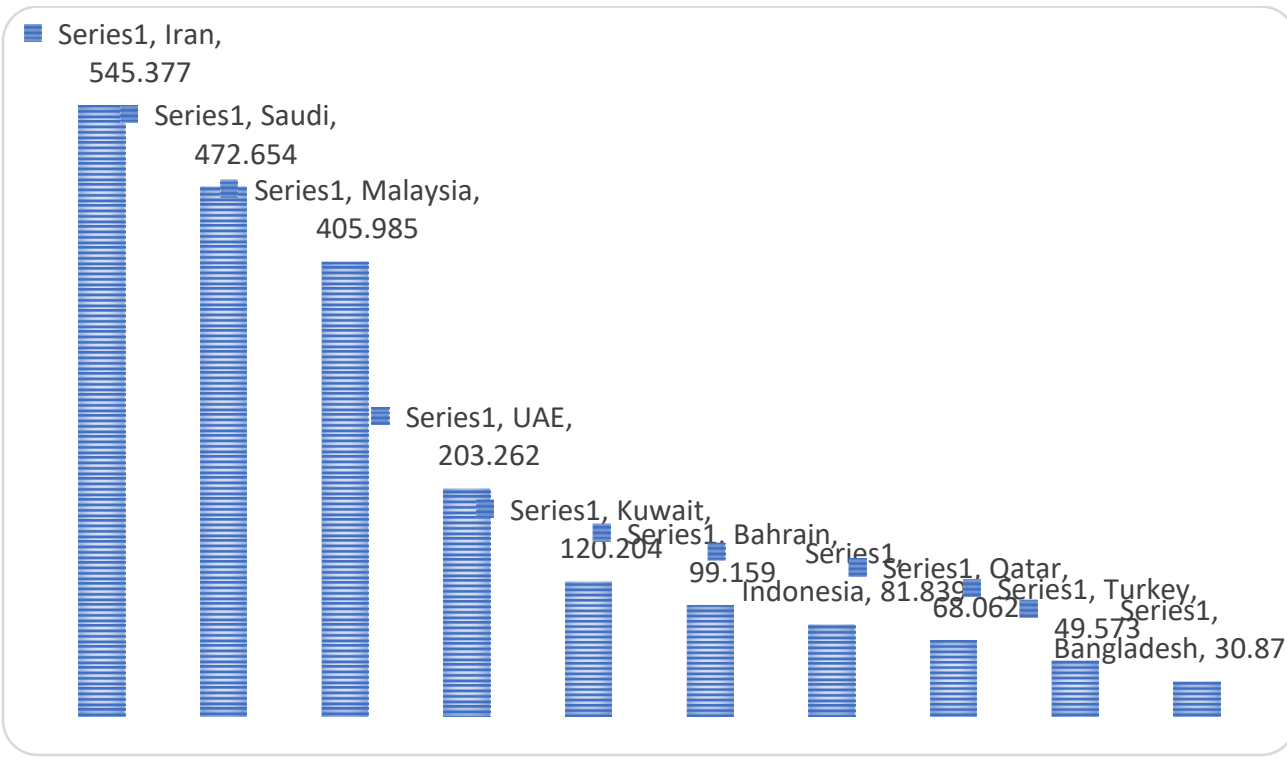

Sumber: Laporan Islamic Fund Management Tahun 2018 Gambar 1. Total Aset Keuangan Syariah

Secara regional Asia Tenggara, Indonesia dan Brunei dinilai sebagai negara yang paling baik perkembangan keuangan syariahnya. Brunei berkembang disemua indikator keuangan syariah berdasarkan laporan ICD-Thomson Retuters, sedangkan membaiknya posisi Indonesia pada total aset keuangan syariah terutama didorong oleh perkembangan pesat di sektor pasar modal syariah dan industri keuangan nonbank (IKNB). 
Pada aspek lain, pasar modal merupakan indikator perekonomian suatu negara. Pasar Modal mempunyai peranan penting dalam pembangunan ekonomi sebuah negara. Pasar modal merupakan saluran penting bagi sektor korporasi untuk meningkatkan modal yang dibutuhkan untuk investasi dan kegiatan bisnis (Shin dan Thaker, 2017). Perkembangan pasar modal pada setiap negara dapat di lihat pada gambar berikut ini:

Tabel 1

Perkembangan Gambar 1. Total Aset Keuangan Syariah

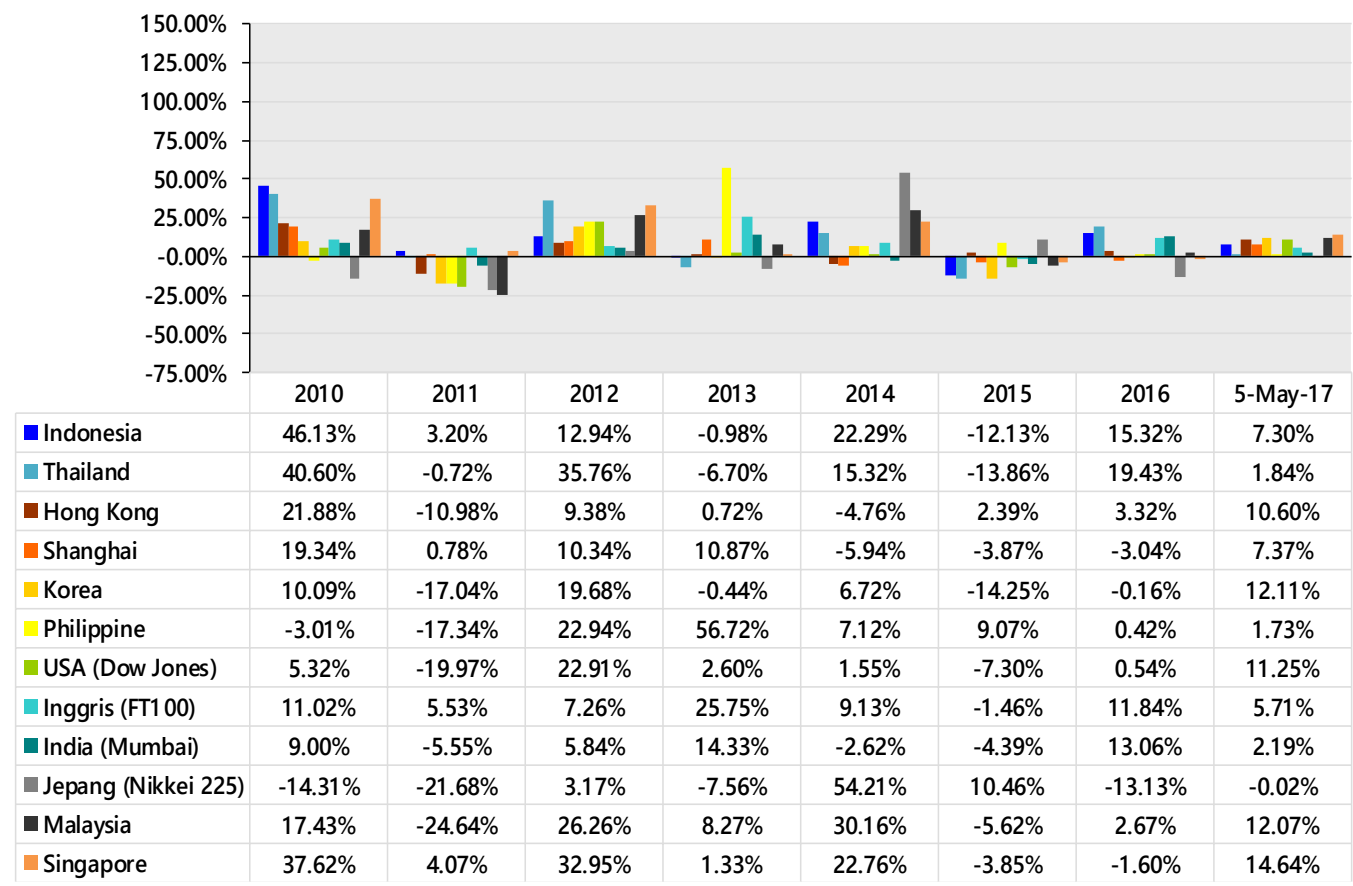

Sumber: Data Statistik PT Bursa Efek Indonesia Tahun 2017

Perkembangan pasar modal Indonesia mengalami peningkatan setiap tahunnya. Pasar modal melakukan fungsi kunci dalam menyediakan hubungan kritis yang diperlukan antara perusahaan yang membutuhkan dana untuk memulai bisnis baru atau untuk memperluas operasi mereka saat ini dan investor yang memiliki dana surplus untuk berinvestasi di perusahaan tersebut (Avdalovic dan Milenkovic 2017).

Indonesia satu dari negara muslim terbesar di dunia merupakan pasar yang besar untuk mengembangkan industri keuangan syariah. Investasi syariah di pasar modal memiliki peran untuk mengembangkan pangsa pasar industri keuangan syariah di Indonesia.Perkembangan pasar modal syariah semakin meningkat dengan lahirnya Indeks Saham Syariah Indonesia (ISSI) pada bulan Mei tahun 2011 dan Jakarta Islamic Index 70 (JII7) pada tahun 2018. Berbeda dengan lainnya pasar modal syariah juga terdapat Jakarta Islamic Index (JII) yang didirikan pada bulan Juli tahun 2000. Berbeda dengan JII, ISSI merupakan indeks saham syariah yang beranggotakan seluruh saham syariah yang dahulunya terdaftar di IHSG bergabung dengan saham non-syariah 
lainnya dan tergabung pada Daftar Efek Syariah (DES). Sedangkan JII70 terdiri dari 70 saham syariah yang memiliki kapitalisasi terbesar.

Secara sederhana, pasar modal syariah dapat diartikan sebagai pasar modal yang menerapkan prinsip-prinsip Islam dalam kegiatan transaksi ekonomi dan terlepas dari hal-hal yang dilarang seperti: riba, perjudian, spekulasi, dan lai-lain. Pasar modal syariah secara resmi diluncurkan pada tanggal 14 maret 2003 bersamaan dengan penandatanganan MOU antara Bapepam dengan Dewan Syariah Nasional-Majelis Ulama Indonesia (DSN-MUI).

Menurut Ardana (2016), dalam satu dekade terakhir menunjukkan beberapa krisis ekonomi yang mengejutkan dunia seperti krisis subprime mortgage yang terjadi di Amerika Serikat pada 2008 dan krisis utang yang terjadi di Eropa pada 2010. Krisis mengguncang sistem perbankan dan sektor keuangan, tidak hanya di Amerika Serikat tetapi meluas ke Eropa dan Asia. Penelitian yang dilakukan oleh Wardana, dkk (2011) menunjukkan bahwa meskipun pasar modal syariah dipengaruhi oleh perubahan harga pasar yang disebabkan oleh krisis keuangan di Amerika Serikat, dampak krisis lebih dirasakan oleh pasar modal konvensional. Pasar modal syariah terbukti memiliki kemampuan yang lebih baik untuk beradaptasi terhadap perubahan dari gangguan krisis eksternal. Dengan demikian, disimpulkan bahwa pasar modal syariah memiliki lebih banyak resistensi terhadap krisis dari pada yang konvensional.

Indeks harga saham adalah indikator yang menunjukkan pergerakan harga saham. Indeks saham berfungsi sebagai indikator tren pasar. Dengan kata lain, pergerakan indeks menggambarkan kondisi pasar pada suatu waktu, apakah pasar aktif pada perdagangan atau sebaliknya. Berdasarkan analisis yang dilakukan oleh Bursa Efek Indonesia dan Bapepam LK saham-saham syariah meningkat setiap tahunnya dapat dilihat dari grafik pergerakan indeks harga saham syariah di bawah ini

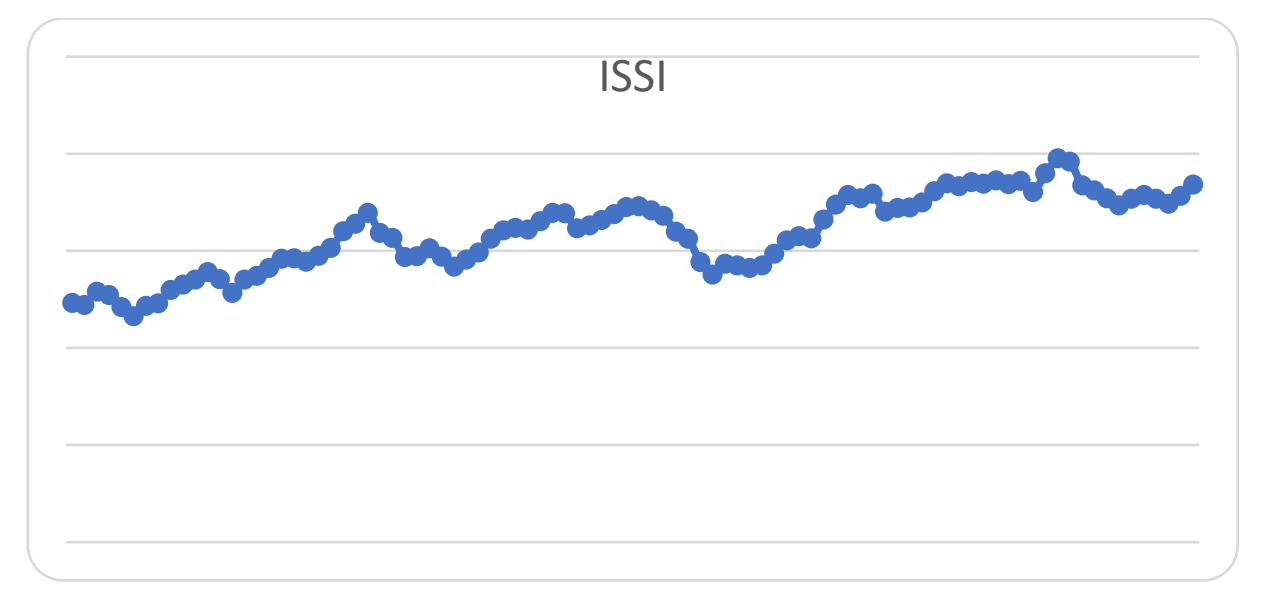

Sumber: laporan Otoritas Jasa Keuangan Data Tahun 2018

Gambar 2. Perkembangan Indeks Harga Saham Syariah Indonesia 
Berdasarkan grafik di atas terlihat untuk jangka panjang pergerakan index menunjukkan tren yang positif dan meningkat signifikan terutama setelah krisis global 2008 yang lalu. Laporan tahunan Bank Indonesia menjelaskan beberapa faktor pendorong positifnya kinerja pasar modal di Indonesia antara lain: membaiknya persepsi investor asing terhadap tingkat risiko di Indonesia, serta selisih suku bunga yang cukup signifikan sehingga memicu arus modal masuk untuk mendapatkan keuntungan jangka pendek, dan kestabilan ekonomi makro dan prospek peningkatan pertumbuhan ekonomi yang cukup signifikan disela perekonomian global yang cenderung lesu mengakibatkan pemodal asing mulai melirik pasar modal Indonesia.

Studi tentang faktor-faktor yang mempengaruhi harga saham tetap menjadi bidang penelitian keuangan yang 228nstrum. Selama beberapa 228nstru terakhir, interaksi harga saham dan variabel makroekonomi telah menjadi subjek yang menarik di kalangan akademisi dan praktisi. Selama beberapa tahun terakhir, terdapat penelitian yang dilakukan di negara berkembang seperti Roubaud dan Arouri (2018), Antonakakis, Gupta, dan Tiwari (2017), Naifar (2016), Mohd Hussin (2012), Hosseini, S. M dan Ahmad, Zamri (2011), Abbas (2011), Hussainey K. dan Ngoc Khan (2009), Asmy (2009), Ibrahim dan Yusoff (2001), Maysami dan Koh (2000), Kwon (1999), Mookerjee dan Yu (1997), Habibullah dan Baharumshah (1996). Dalam penelitian ini variabel makro yang digunakan yaitu, nilai tukar, suku bunga, indeks produksi (IPI), sertifikat Bank Indonesia syariah (SBIS) dan inflasi. Beberapa variabel tersebut diperkirakan mampu mempengaruhi fluktuasi pergerakan indeks harga saham syariah.

\section{LANDASAN TEORI}

Investasi sebagai salah satu bagian dari aktivitas perekonomian tidak dapat mengabaikan aspek postulat, konsep, serta diskursus yang menjadi background dalam pembentukan sebuah pengetahuan yang memiliki multidimensi yang mendasar dan mendalam. Islam sangat menjunjung tinggi ilmu pengetahuan yang memiliki gradasi (tadrij), dari tahapan diskursus (ilmu al yaqin), implementasi ('ain al yaqin), serta hakikat akan sebuah ilmu (haqq al yaqin). Scheller dalam trichotomy pengetahuan menjelaskan bahwa ada 3 jenis pengetahuan, yaitu pengetahuan instrumental (herrschafswissen), pengetahuan intelektual (beldungswissen), dan pengetahuan spiritual (erlosungswissen) sebagaimana dituangkan oleh Rich dalam bukunya the knowledge cycle (Huda dan Nasution, 2008).

Investasi merupakan salah satu ajaran dari konsep Islam yang memenuhi proses tadrij dan trichotomy pengetahuan tersebut. Hal tersebut dapat dibuktikan bahwa konsep investasi selain sebagai pengetahuan juga bernuansa spiritual karena menggunakan norma Islam, sekaligus merupakan hakikat dari sebuah ilmu dan amal, oleh karenanya investasi sangat dianjurkan bagi setiap muslim. Hal tersebut dijelaskan dalam Al-Qur'an surat Al-Hasyr ayat 18 sebagai berikut:

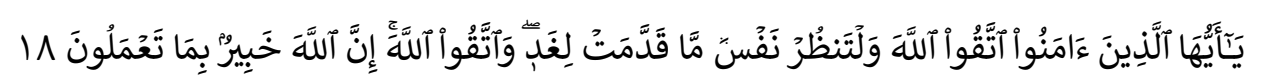


Yā ayyuhallażīna āmanuttaqullāha waltanẓur nafsum mā qaddamat ligad, wattaqullāh, innallāha khabìrum bimā ta'malụn

"Hai orang-orang yang beriman, bertakwalah kepada Allah dan hendaklah setiap diri memperhatikan apa yang telah diperbuatnya untuk hari esok (akhirat); dan bertakwalah kepada Allah, sesungguhnya Allah Maha Mengetahui apa yang kamu kerjakan" (QS 59: 18. Departemen Agama RI, 2004)

Lafaz waltanzhur nafsummaqaddamat Ihighat ditafsirkan dengan hitung dan intropeksilah diri kalian sebelum diintropeksi, dan lihatlah apa yang telah kalian simpan (invest) untuk diri kalian dari amal saleh sebagai bekal kalian menuju hari perhitungan amal pada hari kiamat untuk keselamatan diri di depan Allah SWT. Demikian Allah SWT memerintahkan kepada seluruh hamba-hambanya yang beriman untuk melakukan investasi akhirat dengan melakukan amal saleh sejak dini sebagai bekal untuk menghadapi hari perhitungan. Ayat ini juga secara eksplisit menegaskan kepada manusia untuk selalu berinvestasi baik dalam bentuk 229nstrum untuk bekal di akhirat nanti. Investasi adalah bagian dari muamalah 229nstrum, sehingga kegiatannya mengandung pahala dan bernilai ibadah bila diniatkan dan dilaksanakan sesuai dengan prinsip syariah.

Dalam Al-Qur'an surat Lukman ayat 34 secara tegas Allah SWT. Menyatakan bahwa tiada seorang pun di alam semesta ini yang dapat mengetahui apa yang akan diperbuat, diusahakan, serta kejadian apa yang akan terjadi pada hari esok. Sehingga dengan ajaran tersebut seluruh manusia diperintahkan untuk melakukan investasi sebgai bekal dunia dan akhirat :

Innallāha 'indahụ 'ilmus-sā'ah, wa yunazzilul-gaīs, wa ya'lamu mā fil-ar-ḥām, wa mā tadrī nafsum mā̇̇ā taksibu gadā, wa mā tadrī nafsum bi ayyi arḍin tamụt, innallāha 'alīmun khabìr

Artinya: 34. Sesungguhnya Allah, hanya pada sisi-Nya sajalah pengetahuan tentang Hari Kiamat; dan Dialah Yang menurunkan hujan, dan mengetahui apa yang ada dalam 229nstr. Dan tiada seorangpun yang dapat mengetahui (dengan pasti) apa yang akan diusahakannya besok. Dan tiada seorangpun yang dapat mengetahui di bumi mana dia akan mati. Sesungguhnya Allah Maha Mengetahui lagi Maha Mengenal. (QS 31:34. Departemen Agama RI, 2004)

Dalam kitab Zubdatul Tafsir karya Al-Asyqar lafaz madza taksibughoda ditafsirkan dengan man kasbu addin aukasbuddunya yang dalam bahasa Indonesia diterjemahkan "dari usaha untuk bekal akhirat ataupun usaha untuk bekal dunia" (Huda dan Nasution, 2008: 19).

\section{Kurs}


Uang merupakan alat tukar yang diterima secara umum. Persoalnnya lebih rumit ketika menyangkut urusan di luar batas negara. Karena pada umumnya perdagangan antar negara dapat berlangsung jika dimungkinkan menukar mata uang suatu negara menjadi uang negara lain. Menurut Mishkin (2008: 136) Nilai tukar atau biasa disebut kurs merupakan harga dari mata uang suatu negara dengan negara lain. Kurs atau valuta asing juga diartikan sebagai alat pembayaran yang digunakan untuk melakukan transaksi ekonomi keuangan internasional dan mempunyai catatan kurs resmi pada bank sentral.

Hasil penelitian sebelumnya menunjukkan bahwa nilai tukar rupiah terhadap USD memiliki efek negatif dan positif signifikan. Asmy, Rohilina, Hassama dan Fouad (2010) mencoba untuk menguji hubungan kausal jangka pendek dan jangka panjang antara Kuala Lumpur Composite Index (KLCl) dan variabel makroekonomi. Hasilnya menunjukkan bahwa nilai tukar secara signifikan mempengaruhi Kuala Lumpur Composite Index (KLCl). Hasil ini juga mendukung penelitian Sakti dan Harun (2013), Masrizal dkk (2019) menyatakan dalam jangka panjang terdapat hubungan positif antara Jll dan nilai tukar.

\section{Suku Bunga}

Suku bunga merupakan biaya pinjaman yang dibayarkan untuk dana pinjaman. Menurut Mishkin (2008:4) Suku bunga mempunyai dampak pada kesehatan perekonomian secara keseluruhan karena suku bunga tidak hanya dapat memengaruhi kesediaan konsumen untuk mengonsumsi atau menabung tapi juga memengaruhi keputusannya dalam berinvestasi.

Maysami dan Koh (2000), Menggunakan metodologi Johansen menemukan bahwa inflasi, pertumbuhan jumlah uang beredar, perubahan suku bunga jangka pendek dan jangka panjang, dan variasi nilai tukar memang membentuk hubungan kointegrasi dengan perubahan tingkat pasar saham Singapura. Jareno and Negrut (2016), menguji pasar saham Amerika dan faktor ekonomi makro menyatakan bahwa terdapat hubungan negatif antara suku bunga dan pasar saham Amerika.

Peiro (2016) menguji harga saham dan makroekonomi Francis, Jerman and U.K dari 1969 sampai 2013 menyatakan bahwa indeks produksi dan suku bunga memiliki kepentingan yang relatif sama dalam penentuan harga saham. Pada periode pertama suku bunga adalah faktor utama, sedangkan dalam beberapa tahun terakhir variabel produksi yang menjadi faktor utama. Camilleri, Scicluna and Bai (2019) menguji pasar saham dan ekonomi makro pada negara Eropa tepilih yaitu Belgium, Francis, Jerman, Belanda dan Portugal menemukakan bahwa hubungannya negatif dalam kasus Belgia dan Portugal, sedangkan negara-negara lainnya arahnya positif

Abugri (2008) menyelidiki perang suku bunga pada pasar Amerika Latin menyatakan hubungan negatif signifikan antara indeks dan tingkat bunga pada Brasil, Argentina dan Chili, sedangkan suku bunga menjelaskan tidak signifikan pada Meksiko. 
Hal senada juga dikemukakan oleh Ratanapakorn and Sharma (2007) menemukan hubungan negatif antara suku bunga dengan pasar saham Amerika Serikat S\&P500 dalam jangka panjang namun positif dalam jangka pendek.

\section{Indeks Produksi Industri}

Nilai indeks produksi industri adalah ukuran murni dari output, sehingga memiliki nilai yang dekat dengan nilai PDB riil. Indeks produksi industri mengukur perubahan volume produksi yang terjadi dari berbagai sektor produksi seiring waktu. Volume yang diukur mencakup hampir semua sektor produksi di negara ini (kecuali pertanian dan jasa) yaitu pertambangan dan penggalian, manufaktur, listrik, gas, dan konstruksi. Indeks produksi industri adalah informasi yang digunakan oleh investor untuk menentukan perusahaan tempat yang akan diinvestasikan, tentu saja di perusahaan yang memiliki kinerja baik dan memiliki pertumbuhan jangka panjang. Penelitian oleh Beik \& Fatmawati (2014) menemukan efek positif yang signifikan dari IPI pada Indeks Islam Jakarta. Hasilnya konsisten dengan penelitian Savasa dan Samiloglub (2010), Hosseini et al., (2011), Bekhet dan Mugableh, (2012). Peningkatan IPI akan mempengaruhi harga saham melalui dampaknya terhadap laba perusahaan.

\section{Sertifikat Bank Indonesia Syariah}

Sertifikat bank Indonesia merupakan surat berharga yang diterbitkan oleh bank Indonesia dengan tujuan sebagai sarana pengendalian kebijakan moneter melalui Operasi Pasar Terbuka. Penelitian Beik menemukakan bahwa SBIS berpengaruh negaif signifikan terhadap Jakarta Islamic Index. Hasil ini mengindikasikan bahwa SBIS di mata investor merupakan 231nstrument substitusibagi JII, sehingga kenaikan di salah satu 231 nstrumentakan menyebabkan penurunan pada 231 nstrument yang lain.

\section{Inflasi}

Inflasi dianggap sebagai salah satu peristiwa moneter paling penting yang ditemukan di hampir semua penelitian tentang saham di Indonesia. Inflasi adalah kecenderungan kenaikan harga secara umum dan terus menerus (Boediono, 2014). Kenaikan harga hanya satu atau dua item tidak memerlukan inflasi, kecuali jika kenaikan meluas ke sebagian besar harga barang lainnya. Tingkat inflasi yang tinggi menyebabkan uang kehilangan nilainya dan membuat kesulitan untuk tujuan investasi. Fama (1981) dan Asprem (1989) melakukan penelitian tentang hubungan inflasi dengan return saham, yang menunjukkan bahwa korelasi negatif dan kuat antara inflasi dan harga dan pengembalian saham.

Sebuah studi oleh Antonakakis, Gupta, \& Tiwari (2017) bertujuan untuk menguji korelasi antara harga saham dan pengembalian pasar saham pada berbagai waktu selama periode 1791-2015 di Amerika Serikat. Hasil penelitian menunjukkan bahwa korelasi antara informasi inflasi dan pengembalian pasar saham di Amerika Serikat 
berkembang secara heterogen dari waktu ke waktu. Secara khusus, korelasi secara signifikan positif di tahun 1840-an, 1860-an, 1930-an dan 2011, dan sebaliknya negatif.

\section{METODE PENELITIAN}

Pendekatan penelitian yang digunakan dalam penelitian ini adalah pendekatan kuantitatif yang bertujuan menguji hipotesis dengan data yang terukur dan menghasilkan kesimpulan yang dapat digeneralisir. Menurut Sugiyono (2009); penelitian kuantitatif dapat diartikan sebagi metode penelitian yang berlandaskan pada filsafat posistivism, digunakan untuk meneliti pada polulasi atau sampel tertentu, random, pengumpulan data menggunakan instrument penelitian, analisis data bersifat kuantitatif atau statistic dengan tujuan untuk menguji hipotesis yang telah ditetapkan.

Jenis data yang digunakan dalam penelitian ini adalah data sekunder terdiri dari indeks harga saham syariah (ISSI), suku bunga, indeks produksi industri, SBIS dan inflasi berupa data time series pada periode Januari 2011 sampai Desember 2018. Data sekunder tersebut di dapat dari Bursa Efek Indonesia (BEI), Bank Indonesia (BI), Badan Pusat Statistik (BPS).

Teknik analisis yang digunakan dalam penelitian ini adalah menggunakan pendekatan kuantitatif dengan metode Vector Error Correction Model yang diolah dengan menggunakan Eviews 9. Gambar di Bawah ini menjelaskan lebih rinci proses analisis

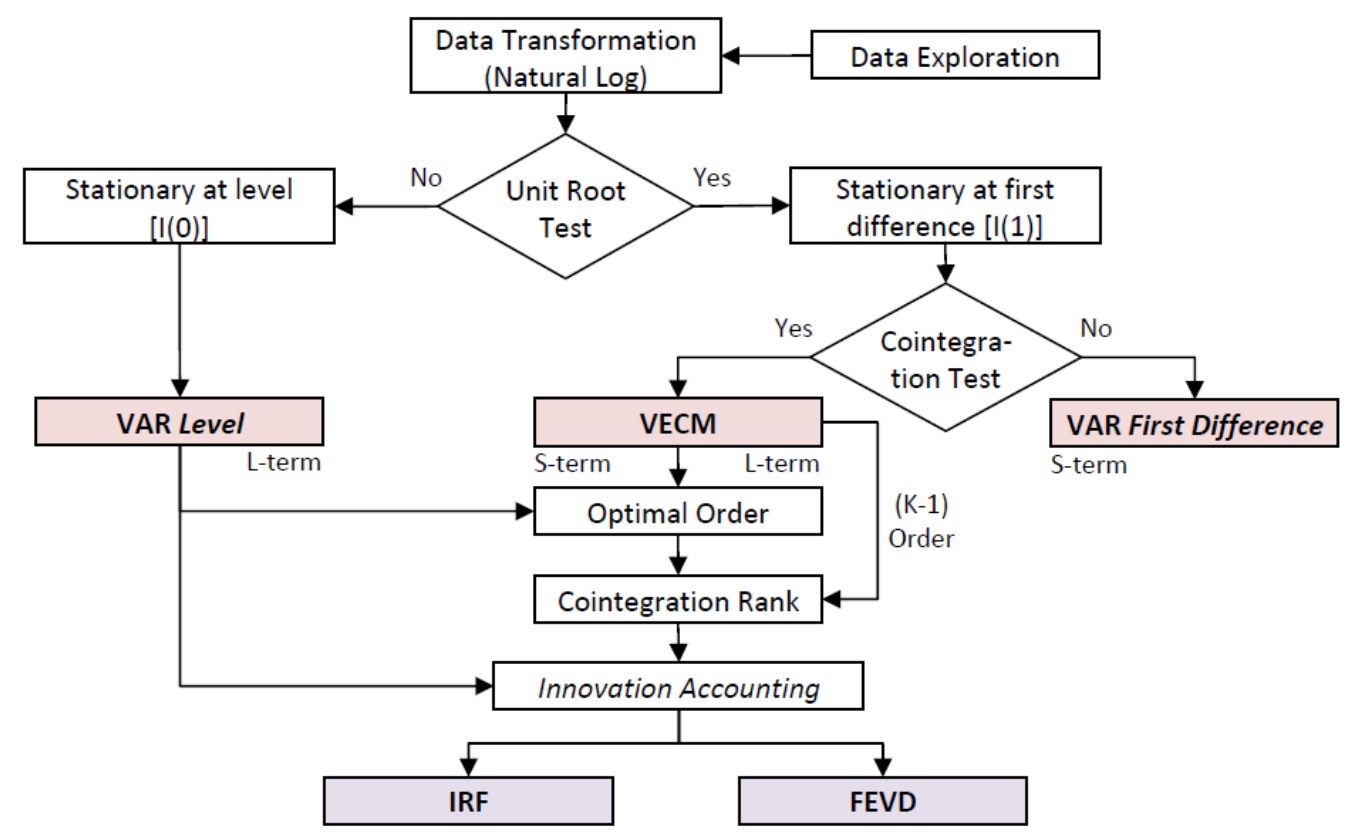

Sumber: Ascarya (2007)

Sumber: Ascarya. 2007. Ekonometrika Teori dan Aplikasi. Jilid I. Jakarta: Mitra Wacana Media

Gambar 3. Alur Proses VECM 


\section{HASIL DAN PEMBAHASAN}

Uji data stasioner biasanya dilakukan dengan menggunakan Root Test Unit. Data stasioner diperlukan untuk menghindari masalah regresi salah. Oleh karena itu, dalam penelitian ini, Uji Unit Akar diterapkan menggunakan prosedur Augmented Dickey Fuller (ADF) di mana jika nilai ADF statistic lebih besar dari Mackinnob critical value atau nilai probabilitas ADF lebih kecil dari tingkat signifikansi $0.05 \%$ maka data tidak mengandung unit root sehingga data dikatakan stasioner. Adapun hasil dari pengujian ditunjukkan pada Tabe 4.7 di bawah ini.

Tabel 2

Stationary Test Result on Level

\begin{tabular}{ccccc}
\hline \multicolumn{4}{c}{ Hasil Uji Stasioneritas data } \\
\hline Variable & \multicolumn{3}{c}{ Level } & \multicolumn{2}{c}{ First difference } \\
& T-statistich & Prob Adf & T-statistich & Prob Adf \\
LnISSI & -1.992713 & 0.2896 & -7.254487 & $\mathbf{0 . 0 0 0}$ \\
LnKURS & -1.587345 & 0.4849 & -10.26240 & $\mathbf{0 . 0 0 0}$ \\
BIRate & -1.604688 & 0.4760 & -6.288018 & $\mathbf{0 . 0 0 0}$ \\
LnIPI & -0.340702 & 0.9134 & -12.26261 & $\mathbf{0 . 0 0 0}$ \\
SBIS & -2.155147 & 0.2241 & -5.800471 & $\mathbf{0 . 0 0 0}$ \\
LnOIL & -0.130014 & 0.6374 & -8.770247 & $\mathbf{0 . 0 0 0}$ \\
Inflasi & -2.167565 & 0.2195 & -7.392459 & $\mathbf{0 . 0 0 0}$ \\
\hline
\end{tabular}

Hasil uji stasioneritas pada pada table di atas menunjukkan bahwa semua data yang digunakan dalam penelitian ini stasioner pada tingkat first differe. Setelah data stasioner pada I(1) maka dilanjutkan dengan pengujian kointegrasi. Hasil uji kointegrasi dilakukan dengan pendekatan Johansen test ditemukan terdapat kointegrasi hubungan jangka panjang antar variabel.

Tabel 3

Hasil Uji Kointegrasi

\begin{tabular}{ccccc}
\hline \hline $\begin{array}{c}\text { Hypothesiz } \\
\text { ed }\end{array}$ & & Trace & 0.05 & \\
\hline No. of CE(s) & Eigenvalue & Statistic & Critical Value & Prob. $^{* *}$ \\
\hline \hline None ${ }^{*}$ & 0.344268 & 106.3690 & 95.75366 & 0.0076 \\
\hline At most 1 & 0.316590 & 68.81076 & 69.81889 & 0.0600 \\
\hline At most 2 & 0.185147 & 34.93198 & 47.85613 & 0.4516 \\
\hline At most 3 & 0.100891 & 16.70948 & 29.79707 & 0.6615 \\
\hline At most 4 & 0.042698 & 7.244227 & 15.49471 & 0.5494 \\
\hline
\end{tabular}


The Effect of Macroeconomic Variables in Predicting Indonesian Sharia Stock Index

\begin{tabular}{lllll}
\hline At most 5 & 0.037056 & 3.360624 & 3.841466 & 0.0668 \\
\hline \hline Trace test indicates 1 cointegrating eqn(s) at the 0.05 level & \\
\hline
\end{tabular}

Tabel 3.

Unrestricted Cointegration Rank Test (Maximum Eigenvalue)

\begin{tabular}{ccccc}
\hline Hypothesized & \multicolumn{3}{c}{ Max-Eigen } & 0.05 \\
\hline No. of CE(s) & Eigenvalue & Statistic & Critical Value & Prob. $^{* *}$ \\
\hline None & 0.344268 & 37.55824 & 40.07757 & 0.0936 \\
\hline At most 1 & 0.316590 & 33.87878 & 33.87687 & 0.0500 \\
\hline At most 2 & 0.185147 & 18.22250 & 27.58434 & 0.4767 \\
\hline At most 3 & 0.100891 & 9.465254 & 21.13162 & 0.7932 \\
\hline At most 4 & 0.042698 & 3.883603 & 14.26460 & 0.8714 \\
\hline At most 5 & 0.037056 & 3.360624 & 3.841466 & 0.0668 \\
\hline
\end{tabular}

Max-eigenvalue test indicates no cointegration at the 0.05 level

Hasil uji kointegrasi pada table di atas menunjukkan bahwa terdapat satu persamaan yang ditandai nilai trace statistic lebih besar dari pada nilai kritis $5 \%$ dan demikian halnya dengan nilai Max-Eigen lebih besar dari nilai kritis 5\%. Hasil ini menunjukkan bahwa terdapat kointegrasi dari variabel-variebl dalam penelitian yang cenderung bergerak menuju ekulibrium pada jangka panjang.

Setelah masing-masing variabel stasioner pada first difference maka dilanjutkan dengan pengujian kointegrasi. Hasil pengujian kointegrasi dalam penelitian ini ditemukan terdapat kointegrasi pada masing-masing variabel. Oleh karena itu teknik analisis yang digunakan dalam penelitian ini adalah Vector Error Correction Model (VECM). Terminologi kointegrasi ini dikenal sebagai error correction karena bila terdapat deviasi terhadap keseimbangan jangka panjang makan akan dikoreksi melalui penyesuaian persial secara bertahap. Nilai error correction term (ECT) mengukur sejauh mana variabel dependen memiliki kecenderungan untuk kembali kepada keseimbangan jangka panjang jika terjadi ketidakseimbangan dalam jangka pendek. Hal ini ditunjukkan hanya ketika nilai ETC yang negatif (Ekananda, 2016: 308). Table di bawah ini merupakan hasil dari estimasi VECM.

Tabel 4

Hasil VECM

\begin{tabular}{ccc}
\hline & Long Term & \\
\hline Variabel & Koefesien & T-statistics \\
LNKURS(-1) & -0.444713 & -1.84715 \\
BIRATE(-1) & 0.007242 & 0.33691 \\
LNIPI & 2.486666 & $\mathbf{5 . 1 6 7 0 2}$ \\
\hline
\end{tabular}




\begin{tabular}{ccc}
\hline SBIS(-1) & -0.036669 & -1.65707 \\
INFLASI(-1) & 0.046134 & 4.53894 \\
& Short Term & \\
CointEq1 & -0.057874 & -1.00900 \\
D(LNISSI(-1)) & 0.278426 & 1.88237 \\
D(LNISSI(-2)) & 0.095272 & 0.66917 \\
D(LNKURS(-1)) & -0.217860 & -1.08431 \\
D(LNKURS(-2)) & 0.365445 & 1.81270 \\
D(BIRATE(-1)) & -0.004569 & -0.22529 \\
D(BIRATE(-2)) & -0.009081 & -0.42110 \\
D(LNIPI(-1)) & -0.131002 & 0.97258 \\
D(LNIPI(-2)) & -0.156652 & -1.37932 \\
D(SBIS(-1)) & 0.011162 & 0.61553 \\
D(SBIS(-2)) & -0.031707 & -1.72803 \\
D(INFLASI(-1)) & 0.003959 & 0.70683 \\
D(INFLASI(-2)) & 0.000258 & 0.04338 \\
D(LNIPI(-1)) & -0.014719 & -0.13621 \\
D(LNIPI(-2)) & -0.201897 & -1.90421 \\
\hline
\end{tabular}

Berdasarkan hasil estimasi VECM di atas, didapat nilai ECT bernilai negatif. Hal ini menjelaskan bahwa adanya hubungan keseimbangan jangka panjang antar variabel dan indeks saham syariah Indonesia (ISSI). Dalam jangka pendek, ketika ada penyimpangan dari jangka panjang, dikoreksi sebanyak 0.057874. Ini adalah penyesuaian kecepatan untuk kembali kekeseimbangan. Pada estimasi jangka pendek, pengaruh variabel yang tidak signifikan karena waktu yang diperlukan (lag) untuk suatu variabel bereaksi terhadap variabel lain. Hasil pengujian membuktikan adanya mekanisme penyesuaian dari jangka pendek ke jangka panjang, yang ditunjukkan oleh kesalahan kointegrasi signifikan dan negatif.

Hasil estimasi VECM jangka panjang menunjukan bahwa kurs tidak mempengaruhi ISSI secara signifikan terhadap ISSI. Temuan ini didukung oleh penelitian Beik (2014) menyatakan bahwa kurs tidak berpengaruh sinifikan terhadap Jakarta Islamic Index. Namun, hasil ini berbeda dengan penelitian Asmy, Rohilina, Hassama dan Fouad (2010) Sakti dan Harun (2013), Masrizal dkk (2019) yang menyatakan kurs yang memiliki hubungan yang signifikan terhadap harga saham. Hal ini mengindikasikan bahwa jumlah investor asing yang menginvestasikan dananya di ISSI tidak terlalu banyak.

Hasil estimasi VECM jangka panjang juga menunjukkan bahwa suku bunga tidak berpengaruh signifikan terhadap ISSI. Hasil ini berbeda dengan penelitian Maysami dan Koh (2000) Jareno and Negrut (2016) Peiro (2016) Camilleri, Scicluna and 
Bai (2019) Abugri (2008) Ratanapakorn and harma (2007) yang menemukan suku bunga merupakan vaiabel yang signifikan mempengaruhi harg saham. Temuan ini menujukkan bahwa suku bunga tidak menjadi acuan investor untuk berinvestasi di saham-saham syariah, karna suku bunga merupakan variabel yang tidak sesuai dengan prinsip dasar saham-saham syariah.

Hasil estimasi VECM jangkan panjang menemukan bahwa indeks produksi industri (IPI) berpengaruh positif signifikan terhadap ISSI. Ketika terjadi kenaikan satu persen dari IPI akan menaikkan ISSI sebesar 2.48666 persen. Hasil ini senada dengan temuan Beikh dan Fatmawati (2014), Savasa dan Samiloglub (2010), Hosseini et al., (2011), Bekhet dan Mugableh, (2012). Apabila terjadi peningkatan pada indeks produksi industri maka siklus bisnis suatu negara tersebut sedang mengalami masa ekspansi dimana produktivitas perusahaan sedang mengalami peningkatan dan begitu pula sebalinya. Peningkatan yang terjadi pada indeks produksi industri diindikasikan bahwa perekonomian mulai tumbuh membaik atau berada dalam masa ekspansi sesuai dengan teori Real Business Cycle. Kondisi ini dinilai sebagai saat yang tepat bagi investor untuk berinventasi dalam bentuk saham. Peningkatan IPI akan mempengaruhi harga saham melalui dampaknya terhadap laba perusahaan.

Hasil temuan VECM juga menunjukkan bahwa SBIS tidak berpengaruh signifikan terhadap ISSI. Hasil ini senada dengan temuan Beikh dan Fatmawati (2014) menemukan SBIS tidak berpengaruh signifikan terhadap Jakarta Islamic Index. Hal ini menarik bahwasanya SBIS dan saham syariah merupakan dua instrument di pasar yang berbeda, sehingga investor mengabaikan SBIS dalam berinvestasi ke dalam sahamsaham syariah. Hasil temuan juga menunjukkan bahwa inflasi berpengaruh signifikan terhadap ISSI. Hal ini senada dengan temuan Tiwari, Dar, Bhanja, Arouri, dan Teulon (2015), Naifar (2016). Pengaruh signifikan inflasi terhadap ISSI ini bahwa Inflasi akan memiliki efek positif jika kenaikan inflasi disebabkan oleh permintaan tinggi atau penawaran produk yang ditawarkan (permintaan inflasi penuh). Dalam situasi ini, perusahaan dapat membebankan kenaikan biaya produksi kepada konsumen, dengan kata lain, kenaikan biaya produksi lebih rendah dari pada kenaikan harga sehingga kinerja dan laba perusahaan meningkat.

Hasil IRF yang ditunjukkan pada gambar di bawah ini, menunjukkan hasil Impulse Response Function dari setiap variabel berbeda-beda. Respon negatif ISSI terhadap nilai tukar terjadi pada bulan kedua sebesar 0,0040. Pada bulan ke tiga respon positif ISSI terhadap nilai tukar ketiga sebesar 0,0015. Namun pada bulan keempat kembali direspon negatif sebesar 0,0006, hingga Pada bulan ke sembilan direspon negatif sebesar 0,0015. Sehingga keadaan mulai stabil ketika bulan ke sepuluh sebesar 0,0014. Respon negatif ISSI terhadap suku bunga juga terjadi pada bulan kedua sebesar 0.0001. pada bulan ke tiga juga berlanjut sebesar 0.0021 . Respon negatif terhadap goncangan suku Bungan berlanjut hingga bulan ke empat belas sebesar 0.0029. Keadaan mulai stabil ditunjukkan pada bulan ke lima belas sebesar 
0.0028. Begitu halnya respon ISSI terhadap SBIS, pada awalnya direspon positif pada bulan kedua sebesar 0.0017. Pada bulan ketiga direspon negatif pada bulan 0.0027, kemudian berlanjut pada bulan ke empat sebesar 0.0077 . Respon negatif terjadi fluktuatif sehingga mulai stabil pada bulan sembilan belas sebesar 0.0052 .

Berbeda dengn respon terhadap indeks produksi industri, goncangan terhadap IPI direspon positif oleh ISSI. Respon positif ISSI terhadap goncangan yang terjadi pada IPI ditunjukkan pada bulan kedua sebesar 0,0006 . Respon positif berlanjut pada bulan keempat sebear 0,0028, hingga berlanjut pada bulan ke lima belas sebesar 0,0056. Respon ISSI mencapai posisi stabil mulai pada bulan keenambelas berkisar 0,0055. Begitu halnya respon terhadap inflasi, goncangan cenderung juga direspon positif oleh ISSI. Pada awalnya, bulan kedua terjadi respon negatif sebesar 0,0007. Pada bulan ketiga direspon positif sebesar 0.0011, hingga berlanjut pada bulan dua belas sebesar 0.0019. Keadaan stabil ketika bulan ke tigabelas dengan respon ISSI terhadap inflasi sebesar 0,0020 . 

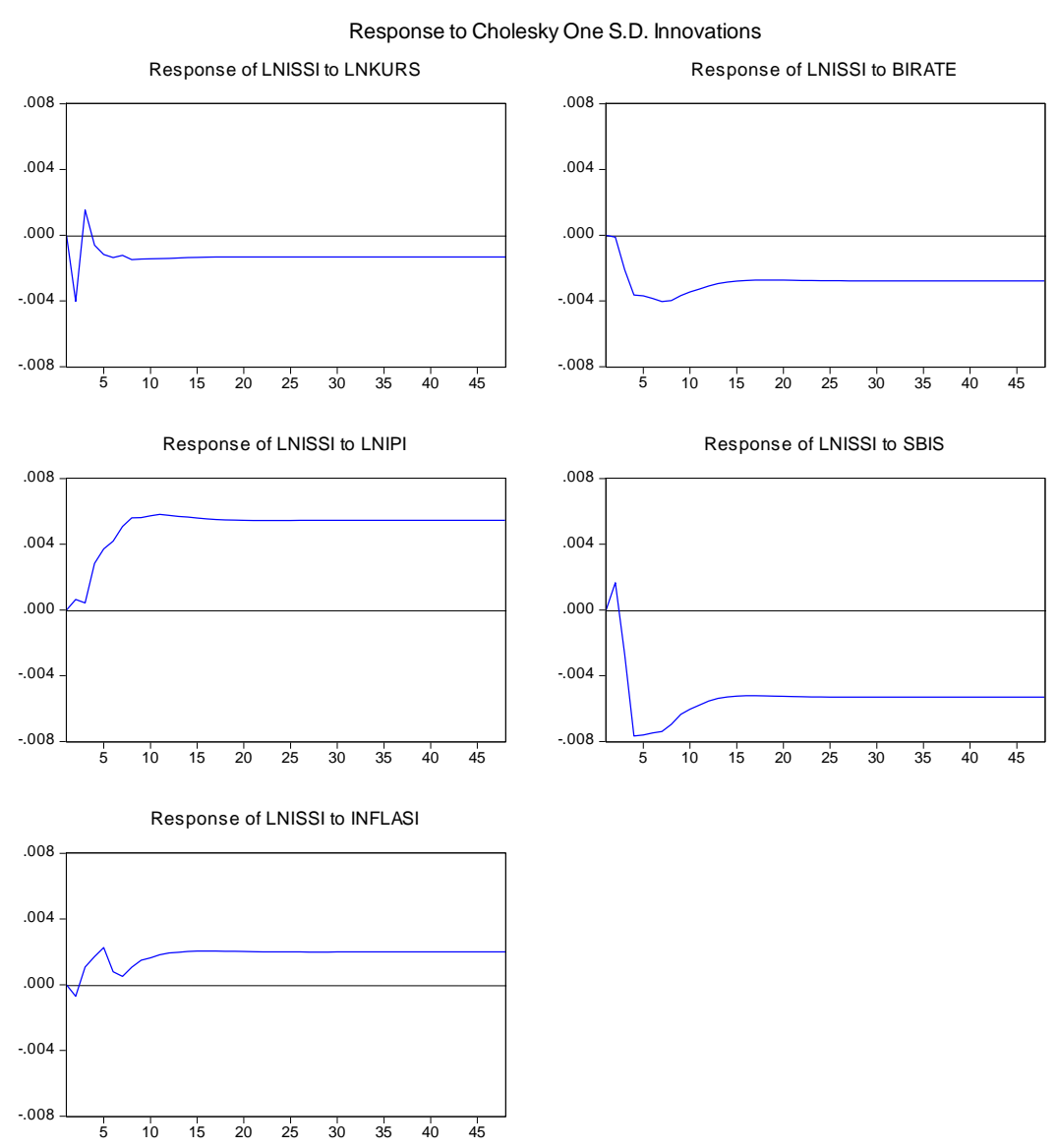

Gambar 4. Grafik IRF

\section{SIMPULAN}

Penelitian ini bertujuan untuk mengeksplorasi hubungan jangka pendek dan jangka panjang antara indeks saham syariah Indonesia dan variabel-variabel makroekonomi yaitu nilai tukar, suku bunga, indeks produksi industri, SBIS dan inflasi. Penelitian ini menggunakan data bulanan dari Januari 2003 hingga Maret 2016. Hasil penelitian menunjukkan bahwa dalam jangka panjang variabel indeks produksi industri dan inflasi berpengaruh signifikan terhadap ISSI, sedangkan nilai tukar, suku bunga dan SBIS tidak berpengaruh signifikan terhadap ISSI. Temuan ini juga memberi gambaran kepada pemerintah agar menjaga kondisi perekonomian sehingga kondisi bisnis berjalan dengan lancar. Hal ini diindikasikan bahwa IPI merupakan variabel terbesar dengan koefisien terbesar dalam mempengaruhi investor menentukan kebijakan investasi.

Respons impuls menunjukkan bahwa guncangan yang terjadi pada nilai tukar, suku bunga dan SBIS direspon negatif oleh indeks saham syariah Indonesia dan akan stabil pada periode yang berbeda untuk setiap variabel. Sementara guncangan yang terjadi dalam indeks produksi industri dan inflasi direspon positif oleh ISSI dan akan stabil dalam periode yang berbeda untuk setiap variabel. Temuan penelitian merekomendasikan penelitian lebih lanjut dengan memasukkan variabel ekonomi makro lainnya seperti PDB, jumlah uang beredar,dan lainnya. 


\section{DAFTAR PUSTAKA}

Abugri, B. A. (2008). Empirical relationship between macroeconomic volatility and stock returns: Evidence from Latin American markets. International Review of Financal Analysis, 17, 396-410.

Avdalovic, Snezana Milosevic \& Milenkovic, Ivan (2017). Impact of Company Performances on The Stock Price: An Empirical Analysis on Select Companies in Serbia.Economics of Agriculture. vol 2. 561-570.

Antonakakis, N., Gupta, R., and Tiwari, A. K. (2017). Research in International Business and Finance Has the correlation of inflation and stock prices changed in the United

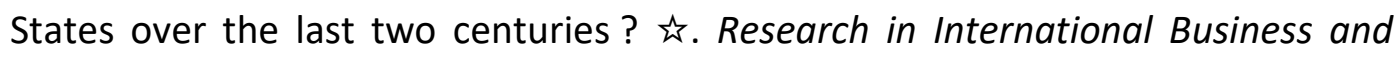
Finance, 42(July2016),1-8

Asmy, M, et al. 2010. Effects of Macroeconomic Variables on Stock Prices in Malaysia: An Approach of Error Correction Model. MPRA Paper. No.20970.

Asprem, M. (1989). Stock prices, asset portfolios and macroeconomic variables in ten European countries. Journal of Banking and Finance, 13(4-5), 589-612. https://doi.org/10.1016/0378-4266(89)90032-0.

Beik, Irfan Syauqi and Fatmawati, Sri Wulan, 2014. Pengaruh Indeks Harga Saham Syariah Internasional dan Variabel Makro Ekonomi Terhadap Jakarta Islamic Index. Allqtishad: Vol.VI No. 2.

Bekhet, H.A. and M.I. Mugableh. 2012. Investigating Equilibrium Relationship between Macroeconomic Variables and Malaysian Stock Market Index through Bounds Tests Approach. International Journal of Economics and Finance. Vol.4 No.10.

Boediono, 2014. Ekonomi Moneter Edisi ketiga, Yogyakarta: BPFE-Yogyakarta.

Fama, E.F., 1981. Stock returns, real activity, inflation and money. Am. Econ. Rev. 71,545565.

Habibullah, M.S. and Baharumshah, A.Z. 1996, Money, output and stock prices in Malaysia: an application of the cointegration tests, International Economic Journal, Vol. 10 No. 2, pp. 121-30.

Hammoudeh, S., Mensi, W., Reboredo, J. C., \& Nguyen, D. K. (2014). Dynamic dependence of the global Islamic equity index with global conventional equity market indices and risk factors. Pacific Basin Finance Journal, 30, 189-206. https: // doi. org/ 10.1016/ j.pacfin. 2014.10.001.

Hosseini, SM, et.al. 2011. The Role of Macroeconomic Variables on Stock Market Index in China and India. International Journal of Economics and Finance. Vol.3 No.6.

Huda, Nurul dan Mustafa Edwin Nasution. 2008. Investasi Pada Pasar Modal Syariah.

Hussainey, Khaled and Le Khan Ngoc. 2009. The impact of macroeconomic indicators on Vietnamese stock prices. The Journal of Risk Finance Vol. 10 No. 4, 2009 pp. 321332.

Ibrahim, M. H and Wan Yusoff, wan sulaiman. 2001. Macroeconomic Variables, exchange rate and stock price: A Malaysia Perspective, IIUM Journal Pf Economics and Management 9, no. 2, 141-163.

Jareno, Francisco and Negrut, Loredana. 2016. US Stock Market And Macroeconomic Factors. The Journal of Applied Business Research. Vol 32, No.1.

Kwon, C.S. and Shin, T.S. 1999, Cointegration and causality between macroeconomic variables and stock market returns, Global Finance Journal, Vol. 10 No. 1, pp. 7181. 
Masrizal., Mustafa, M,U., Herianingrum,S. (2019). Macroeconomic Determinance of Jakarta Islamic Index. The 2nd International Conference on Islamic Economics, Business, and Philanthropy (ICIEBP) Theme: "Sustainability and Socio Economic Growth", KnE Social Sciences, pages 510-524. DOI 10.18502/kss.v3i13.4227.

Maysami, R.C. and Koh, T.S. 2000, A vector error correction model of the Singapore stock market, International Review of Economics and Finance, Vol. 9 No. 1, pp. 79-96

Mishkin, F. (2008). Ekonomi Uang, Perbankan dan Pasar Keuangan (8th ed.). Jakarta: Salemba Empat.

Mookerjee, R. and Yu, Q. 1997, Macroeconomic variables and stock prices in a small open economy: the case of Singapore, Pacific-Basin Finance Journal, Vol. 5 No. 3, pp. 377-88.

Naifar, N. (2016). Do global risk factors and macroeconomic conditions affect global Islamic index dynamics? A quantile regression approach. Quarterly Review of Economics and Finance, 61, 29-39. https://doi.org/10.1016/j.qref.2015.10.004.

Peiro, Amado. 2016. Stock prices and macroeconomic factors: Some European evidence, international review of economics and finance, 41 287-294.

Rusmita, S. A., \& Salleh, M. C. M. (2019). Growth and Value Effect on Jakarta Islamic Index: Analysis towards Performance of Sharia Equity Mutual Fund. Al-lqtishad: Jurnal Ilmu Ekonomi Syariah, 11(1).

Roubaud, D., and Arouri, M. (2018). Oil prices, exchange rates and stock markets underuncertainty and regime-switching. Finance Research Letters, (July 2017), 01.

Sakti, M., \& Harun, Y. (2013). Relationship between Islamis stock prices and macroeconomic variables: Evidence from Jakarta stock exchange islamic index. Global Review of Islamic Economics and Business, 1(1), 71-84. https: // doi.org/ 10.14421/grieb. 2013.011-06.

Shin, W. K \&Thaker, H.M.T (2017), Macroeconomic Variables, Financial Ratios and Property Stock Prices in Malaysia, International Journal Of Business and Innovation 3 (1).

Silvio John Camilleri., Nicolanne Scicluna.,Ye Bai., (2019) do stock markets lead or lag macroeconomic variables? evidence from select european countries. north american journal of economics and finance 48 (2019) 170-186.

Suciningtias, S. A., \& Khoiroh, R. (2015). Analisis Dampak Variabel Makro Ekonomi Terhadap Indeks Saham Syariah Indonesia (Issi). Conference In Business, Accounting, And Management (CBAM), 2(1), 398-412. Retrieved from http://jurnal.unissula.ac.id/index.php/cbam/article/view/323/270.

Sugiyono. 2015. Statistika Untuk Penelitian. Bandung: Alfabeta.

Wisnu Wardana, Wisnu et al (2011), Pasar Modal Syariah dan Krisis Keuangan Global, Iqtishodia Jurnal Ekonomi Islam Republika. 